\title{
MODERN CORPORATE UNIVERSITIES: ETHICAL THREATS AND ETHICAL HOPES
}

\author{
I.Y. Lapshin \\ Peoples' Friendship University of Russia (RUDN University) \\ 6, Miklukho-Maklaya St., 117198, Moscow, Russian Federation
}

\begin{abstract}
The article considers the problem of implementation of ethics as a taught subject into modern business education. Modern business schools reached a stable point of development during last decades and became less adaptive to the needs of modern business community. In this sense, business schools represent a longer educational tradition while education in corporate universities which emerged a half a century ago is grounded upon more innovative and experimental principles. Practical orientation and correlation with the functioning of a specific organization allows corporate universities to avoid several problems accumulated during the decades of business schools' existence. However, the renunciation of some principles which are traditional for both public and private education can potentially lead to contradictory consequences including those in the sphere of ethics.

The first part of the article is a brief historical overview of the development of economic education in the world. It is also shown on the example of the USA why some of features of business schools have developed like we know them today and what is their connection with the various stages of development of the world economy in the $20^{\text {th }}$ century. The second part of the article aims to outline some nuances of the emergence and development of corporate universities, to show why their influence on the modern economic education increased and to point out the corresponding reasons to be ethically concerned.

The article analyses some problems of modern business-schools and also considers corporate universities as an alternative to traditional business education.
\end{abstract}

Key words: business ethics, business schools, corporate universities

The history of economic education is not very long. Modern economic thought traces its history back to the 18th century and the debates between two schools, mercantilists and physiocrats, but economics as a profession taught in universities dates back to as late as the second half of the 19th century when most of the leading economists became academic teachers [1. P. 722]. However, while there were many professional economists which were teaching cognate disciplines, economics as a university subject was presented only by few professors of largest and most prominent universities. At this time, curriculums of several universities had already economic disciplines included, nevertheless, there were still little to no means to conduct research.

The end of the 19th century and the first decade of the 20th was the period when most of the well-known business schools were founded. The Wharton School of the University of Pennsylvania, the University of Chicago Booth School of Business, The College of Commerce of the University of California, the Harvard business school and many others started developing the method which is now commonly known as the casestudy method. One of the reasons for its popularity was the mere absence of suitable textbooks, though today this method is still widely used in economics education. Analysis 
of cases has proven itself viable and effective as an explanation technique which appeals to common sense and general beliefs of a student, immersing him into various realistic situations. Generally, case-study as a teaching method is the more effective the deeper this immersion is, and it inevitably implies that students have to deal not only with logical and mathematical problems. Emotional participation can be welcome or not, but it is always natural. What is more important for us here, studying cases nudges students to make conclusions about integrity or dishonesty of managerial choices discussed during lessons, and occasions that happened in the past usually are followed by consequences with clear ethical meaning. We assume that implementation of case-studies was one of the starting points for ethics in economic education.

During the 1920s the world was separated in two parts: several European countries, e.g. Germany and Austria, were suffering economic decay after the First World War. The Soviet Union was building its economy from the wreckage of the wealth of the pre-revolutionary Russia. To the contrary, American economy was "roaring" in the 1920s. After the end of war, the United States switched its industrial capacities to peaceful purposes. In general, two words could describe the state of the economy of the United States during this period: consumerism and credits. The absence of a united world economic picture stalled the development of economic education. Moreover, this period of American prosperity was relatively short and ended with the Great Depression, and this instability encouraged strictly economic theories, not philosophical and ethical reflections.

After the Second World War there was a relatively fruitful period for economics education in several countries. In the U.S.A. the popularity of economics education grew very quickly, it was declared on the governmental level crucial for the American economy to survive [2. P. 22]. Most European countries were struggling their way out of the post-war devastation. The economy of the Soviet Union became decentralized after the reform of 1957. It was also the time of formation of economic theories which are still valid nowadays such as monetarism and neo-Keynesianism.

The seventies were a decade of growing distrust of social sciences as sciences which also affected economics as a discipline. S. Andreski in his "Social Sciences as Sorcery" (1972) claimed that there was "an abundance of pompous bluff and paucity of new ideas" [3. P. 11] and accused sociologists of inability to articulate their concepts clearly. A. Elms ("The crisis of confidence in social psychology", 1975) stated the shortage of relevant and practical research in social psychology [4]. Similar problems were noted by M. Deutsch (1976) in his "Comments on the Current Status of American Social Psychology" [5]. The growth of scientific psychological literature in this decade lead to a sense of fragmentation among academic readers.

On the other hand, it should be said that these years were fruitful for the development of business schools, the almost only centers of economic education of that time. Furthermore, the growing demand for interdisciplinary research raised the value of business school which could contribute much in this sphere. W. Bennis and J. O'Toole remarked that "during the 1970s and early 1980s, the best business schools were arguably the most intellectually exciting places in academia. In many universities, B schools were 
the primary loci of multidisciplinary research. That intellectual ferment and cross-pollination helped make business schools the hugely popular institutions they are today" [6]. What is most important for our paper, the 1970s was the time when the notion of business ethics came into common use in the United States and also the time when some major books concerning business ethics (such as "Theory of Justice" by J. Rawls) were written.

However, this notion itself seems to be troublesome: business professions are sometimes thought as unethical by their nature. One of the problems is that "discussing ethics makes economics uncomfortable... economics is traditionally viewed as ill-suited to discuss competing ethical norms". This enduring idea hindered the development of business ethics as a taught subject. Nevertheless, Polly Peck and Qintex and later WorldCom and Enron scandals proved that some economic disasters can't be explained only by technical shortcomings: there were bright examples of ethical misconduct among senior executives. We could suppose that these situations should have turned the attention of the business community and national ministries to the lack of ethical training in business schools. Yet, this hypothesis would be at least a little anachronistic: business ethics as a taught subject was widespread already in the 1980s, and, for example, there were more than 500 courses taught in American educational institutions by this time [7]. Some researchers argue that existing systems of business ethics education have flaws which already become inherent in business schools curriculums [8]. Moreover, there are still many business schools which refuse to implement any stand-alone ethics courses [9. P. 2]. The situation with ethics as a subject in business schools becomes more and more confusing.

Despite any economical or ethical crises, business school education still remains very popular as a passport to corporate success. A way of receiving knowledge necessary for doing any business that would totally change the picture can hardly be imagined today. However, corporate universities which emerged in the last decades are functioning on the same ground nowadays. One of the main reasons for corporations to establish their own educational institutions is the intention to preserve intellectual capital [10]. Traditional systems of education presume that a large commercial organization which has its own specific needs and requests has only two opportunities: either to invest into some educational institution in order to be allowed to make some adjustments in the curriculums or to settle for available education. With the rise of corporate universities, the situation has changed: corporate universities allow much more freedom in terms of arranging training courses.

However, despite the fact that first corporate universities emerged in the 19601970s, there are great concerns (especially intensified by science fiction [11]) connected with this freedom corporate universities may enjoy. First of all, it could be presumed that since any corporate university tend to train specialists which later should be employed in a particular corporation, any corporate university tend to be a nonpublic organization which can form shady convictions.

Another important trait of most corporate enterprises today is the distancing from state institutions and governmental regulations, which contradicts the modern idea 
of economics as a profession. As Ludwig von Mises wrote, "the development of a profession of economists is an offshoot of interventionism. The professional economist is the specialist who is instrumental in designing various measures of government interference with business" [12. P. 869]. Modern corporations tend to avoid any influence from the state [13]. This tendency is evident, among other fields, in the sphere of ethics.

There are also some other pessimistic expectations connected with the growth of corporate universities. However, as we showed above, some concerns and anticipations are delusive and based on an anachronistic thinking. Further we will try to demonstrate why corporate universities are competing with more traditional business schools.

First of all, it should be reminded that the history of business education is tightly connected with the development of management as a profession. In the United States, for example, the project of management as a profession started in the beginning of the 20th century [14]. However, management as a profession differs considerably from more traditional specializations. Today it is almost unthinkable to practice as a lawyer or as a physician without having completed the corresponding education. On the contrary, it is common for managers to be educated in psychology, sociology or any other field except management [14]. This situation inclines people to think that management is an "optional" profession, while modern business schools are mostly associated with conferring MBA and similar degrees which exist for more than 50 years and still are very popular. Hence, we should conclude that this is not a temporary shortcoming but an established practice.

It is also becoming some kind of tradition to contrast the economic subjects and ethics in the curriculums of business schools. Nevertheless, as W. Bennis and J. O'Toole suggest, sometimes there is little difference between failures of economic strategy and ethical lapses: both are caused by narrowly specialized business education [6]. Corporate universities, on the contrary, tend to include ethical studies and some other theoretically loaded disciplines into their curriculums.

On the other hand, graduates of today's business schools often lack practical experience. Today's business schools sometimes prefer research over practical teaching: "many of the top-ranked schools sniff at professional school identity, arguing that they are more interested in generating intellectual capital than in following the nuances of 'business as usual' practices in the marketplace" [15. P. 31]. As W. Bennis and J. O'Toole put it, the problem is that too many business school faculty members are practically inexperienced [6].

E. Land, the founder of Polaroid, in his famous speech at MIT suggested that every business school should have its own business. That would mean that such business schools would be reorganized following the model of medical educational institutions where theoretical courses are combined with the practice conducted by students under the supervision of professors. This idea was partly realized in the corporate universities. As D. Guthrie argues, "many corporations are creating their own internal universities because they feel business schools have failed at training the managers and leaders needed to run their companies" [16].

Today's corporate universities are, to a greater or lesser extent, an alternative to business schools. Their curriculums are more flexible and can include disciplines traditionally not studied at business schools. Despite the risks of giving such a freedom 
to educational organizations, this way of composing teaching programs has great perspectives. Financial organizations today "are interested in a clever cross-fertilization between learning and strategy" [17], so, for example, the implementation of specific on-the-job training can be crucial for specialist education.

There are also some misconceptions tightly connected with the traditional business school education. For example, there is a common notion that "society grants to corporations the status of legal persons in order to hold them accountable for their conduct, as any individual citizen would be" [14]. In other words, almost any society wants to see corporations as individuals responsible for their actions as citizens would be. Despite the fact that this concept proved to be more or less viable, there is an important and often neglected difference: the governance of huge corporations is largely decentralized so that in some critical situations there can be no obvious culprit. Society, nevertheless, is usually prone to assume that the CEO or the main executives are always to blame. In the age of large corporations this assumption is at least questionable: some sequences of decisions are made by dozens of managers. In other words, "ethical lapses in business occur not just because a few people are crooks" [18. P. 186]. The Enron case showed that there is more to such disasters than just malpractice of top managers: the lack of corporate culture [19].

Ethics as a part of business education is still often considered as a subject which is not inherent in the typical and essential business curriculum. Yet, it could be seen as a necessary part of corporate culture studies which become more and more important for young managers. We hope that, with time, there will be no need to justify the presence of ethics courses in business education. We also hope that, despite the fact that the idea of corporate university is not new and some corporate universities exist longer than 50 years, corporate business education can improve the ethical climate of modern business.

(C) Lapshin I.Y., 2017

\section{REFERENCES}

[1] Schumpeter JA. History of Economic Analysis. Taylor \& Francis; 2006.

[2] Education for the Economic Challenges of Tommorow: a Report of a Symposium in Conjunction with the 10th Anniversary of the JCEE, 1949-1959. Joint Council of Economic Education. New York. 1959:28-30.

[3] Andreski S. Social Sciences as Sorcery. Andre Deutsch Ltd; 1972.

[4] Elms A. The crisis of confidence in social psychology. American Psychologist. 1975;30(10): 967-976.

[5] Deutsch M. Some Comments on the Current Status of American Social Psychology. The Japanese Journal of Experimental Social Psychology. 1978-1979;18(2):167-171.

[6] Bennis WG, O’Toole J. How Business Schools Lost Their Way [Internet]. Hbr.org. [cited 30 April 2017]. Available from: https://hbr.org/2005/05/how-business-schools-lost-their-way.

[7] De George RT. A History of Business Ethics [Internet]. Scu.edu. [cited 30 April 2017]. Available from: https://www.scu.edu/ethics/focus-areas/business-ethics/resources/a-history-of-business-ethics.

[8] Hillard J, Dent EB. A Positive Approach Answering Business Ethics Educational Ineffectiveness. Academy of Management Proceedings. 2016;1.

[9] Swanson DL, Fisher DG. Advancing Business Ethics Education. Charlotte, NC: Information Age Publishing; 2008. 
[10] Krook S. Boring business ethics: a need for postmodernisation? Learning, Teaching and Social Justice in Higher Education. UoM Custom Book Centre; 2010.

[11] Lapshin IY. Cyberpunk Coming True. The World in 100 Years. Moscow. 2016.

[12] Von Mises L. Human Action. Ludwig von Mises Institute; 1949.

[13] Lapshin IY, Mukhamedzhanova VS, Kosorukova AA. Social Ethics of Corporate Anthem. 3rd International Multidisciplinary Scientific Conference on Social Sciences and Arts SGEM 2016. 2016;3(2):833-840.

[14] Khurana R, Nohria N. It's Time to Make Management a True Profession [Internet]. Hbr.org. [cited 30 April 2017]. Available from: https://hbr.org/2008/10/its-time-to-make-management-atrue-profession/.

[15] Dennis E, Smith S. Finding the Best Business School for You: Looking Past the Rankings. Praeger Publishers; 2006.

[16] Guthrie D. Corporate Universities: An Emerging Threat to Graduate Business Education [Internet]. Forbes.com. [cited 30 April 2017]. Available from: https://www.forbes.com/sites/ dougguthrie/2013/01/22/corporate-universities-an-emerging-threat-to-graduate-businesseducation/\#21b567cb17a0/.

[17] Why Winning Organizations have Corporate Universities [Internet]. C4sl.eu. [cited 30 April 2017]. Available from: http://www.c4sl.eu/why-winning-organizations-have-corporate-universities.

[18] O’Toole J, Mayer D. Good Business: Exercising Effective and Ethical Leadership. Routledge; 2010.

[19] Schuler AJ. Does Corporate Culture Matter?: The Case of Enron [Internet]. Academia.edu. [cited 30 April 2017]. Available from: http://www.academia.edu/6804951/ENRONs_ CORPORATE_CULTURE_Does_Corporate_Culture_Matter_The_Case_of_Enron.

DOI: 10.22363/2313-2302-2017-21-3-389-395

\title{
СОВРЕМЕННЫЕ КОРПОРАТИВНЫЕ УНИВЕРСИТЕТЫ: ЭТИЧЕСКИЕ УГРОЗЫ И ЭТИЧЕСКИЕ НАДЕЖДЫ
}

\author{
И.Е. Лапшин \\ Российский университет дружбы народов \\ 117198, Москва, Россия, ул. Миклухо-Маклая, д. 6
}

В статье рассмотрена проблема внедрения этики как образовательной дисциплины в современное бизнес-образование. Многие современные бизнес-школы за последние десятилетия достигли устойчивой точки развития, и их адаптируемость к нынешним проблемам бизнес-сообщества значительно снизилась. В этом смысле бизнес-школы представляют более длительно существующую традицию в образовании, в то время как процесс обучения в корпоративных университетах, появившихся полвека назад, построен на более новаторских и экспериментальных принципах. Практическая ориентированность и привязка к функционированию конкретной организации позволяют корпоративным университетам избежать в своей деятельности некоторых проблем, накопившихся в течение десятилетий существования бизнес-школ. Тем не менее, отказ от ряда принципов, традиционных как для государственного, так и для частного образования, потенциально может привести к неоднозначным последствиям, в том числе в сфере этики.

Первая часть статьи представляет собой краткий исторический обзор развития экономического образования в мире. На примере США и некоторых других стран показано, почему некоторые черты бизнес-школ сложились именно такими, какими мы их знаем сегодня и какова их связь с различными этапами развития мировой экономики в XX в. Вторая часть статьи имеет своей целью изложить некоторые нюансы возникновения и развития корпоративных университетов и увеличения их влияния на современное экономическое образование, а также указать на возникшие в связи с этим причины для этического беспокойства. 
Статья анализирует некоторые проблемы современных бизнес-школ, а также рассматривает корпоративные университеты в качестве альтернативы традиционному бизнес-образованию.

Ключевые слова: бизнес-этика, бизнес-школы, корпоративные университеты

\section{ЛИТЕРАТУРА}

[1] Schumpeter J.A. History of Economic Analysis. Taylor \& Francis; 2006.

[2] Education for the Economic Challenges of Tommorow: a Report of a Symposium in Conjunction with the 10th Anniversary of the JCEE, 1949 - 1959. New York: Joint Council of Economic Education, 1959. P. 28-30.

[3] Andreski S. Social Sciences as Sorcery. Andre Deutsch Ltd, 1972.

[4] Elms A. The crisis of confidence in social psychology // American Psychologist. 1975. № 30(10). P. 967-976.

[5] Deutsch M. Some Comments on the Current Status of American Social Psychology // The Japanese Journal of Experimental Social Psychology. 1978 - 1979. № 18(2). P. 167-171.

[6] Bennis W.G., O’Toole J. How Business Schools Lost Their Way [интернет]. Hbr.org. [дата обращения: 30.04.2017]. Доступ по ссылке: https://hbr.org/2005/05/how-business-schoolslost-their-way.

[7] De George R.T. A History of Business Ethics [Интернет]. Scu.edu. [Дата обращения: 30.04.2017]. Режим доступа: https://www.scu.edu/ethics/focus-areas/business-ethics/resources/a-historyof-business-ethics/.

[8] Hillard J., Dent E.B. A Positive Approach Answering Business Ethics Educational Ineffectiveness // Academy of Management Proceedings. 2016. № 1.

[9] Swanson D.L., Fisher D.G. Advancing Business Ethics Education. Charlotte, NC: Information Age Publishing, 2008.

[10] Krook S. Boring business ethics: a need for postmodernisation? Learning, Teaching and Social Justice in Higher Education. UoM Custom Book Centre, 2010.

[11] Lapshin I.Y. Cyberpunk Coming True. The World in 100 Years. Moscow, 2016.

[12] Von Mises L. Human Action. Ludwig von Mises Institute, 1949.

[13] Lapshin I.Y., Mukhamedzhanova V.S., Kosorukova A.A. Social Ethics of Corporate Anthem // 3rd International Multidisciplinary Scientific Conference on Social Sciences and Arts SGEM 2016. 2016. № 3(2). P. 833-840.

[14] Khurana R., Nohria N. It's Time to Make Management a True Profession [Интернет]. Hbr.org. [Дата обращения: 30.04.2017]. Режим доступа: https://hbr.org/2008/10/its-time-to-makemanagement-a-true-profession/.

[15] Dennis E., Smith S. Finding the Best Business School for You: Looking Past the Rankings. Praeger Publishers, 2006.

[16] Guthrie D. Corporate Universities: An Emerging Threat to Graduate Business Education [Интернет]. Forbes.com. [Дата обращения: 30.04.2017]. Режим доступа: https://www.forbes.com/ sites/dougguthrie/2013/01/22/corporate-universities-an-emerging-threat-to-graduate-businesseducation/\#21b567cb17a0/.

[17] Why Winning Organizations have Corporate Universities [интернет]. C4sl.eu. [Дата обращения: 30.04.2017]. Режим доступа: http://www.c4sl.eu/why-winning-organizations-havecorporate-universities/.

[18] O’Toole J., Mayer D. Good Business: Exercising Effective and Ethical Leadership. Routledge, 2010.

[19] Schuler A.J. Does Corporate Culture Matter?: The Case of Enron [Интернет]. Academia.edu. [Дата обращения: 30.04.2017]. Режим доступа: http://www.academia.edu/6804951/ ENRONs_CORPORATE_CULTURE_Does_Corporate_Culture_Matter_The_Case_of_Enron.

\section{Сведения об авторе:}

Лапшин Иван Евгеньевич - кандидат философских наук, ассистент кафедры этики факультета гуманитарных и социальных наук; e-mail: lapshin_ie@rudn.university. 